\title{
ReSEARCh ArTiCle \\ Application of reflectance based vegetation index to derive dual crop co-efficient for summer sesame
}

\author{
A. P. Lakkad ${ }^{*}$, S. G. Patel ${ }^{2}$, Vibhuti A. Patel ${ }^{3}$ and M. G. Varma ${ }^{4}$
}

\begin{abstract}
SUMMARY
Dual crop co-efficient approach was applied to estimate seasonal water requirement for summer sesame using reflectance based vegetation indices. Field experiment was conducted to collect the required various crop physiologic parameters and NDVI data for the study crop during 2018 and 2019. Basal crop co-efficients and soil evaporation co-efficients collected from FAO-56 for initial mid and end stages of summer sesame were adjusted for study area using local weather parameters. Spectrum ${ }^{\circledR}$ Field Scout CM 1000 NDVI Meter were used to collect the NDVI data at various stages of study crop. The NDVI was measured from crop canopy and soil surface at 7 days intervals between 12.00 to 13.00 clocks. NDVI Based Basal Crop Co-efficient and Soil evaporation co-efficient were derived using standard methods. FAO estimated crop co-efficients were compared with NDVI based crop co-efficients. The co-efficient of determination of the fitted regression equation was found to be 0.836 and 0.765 for drip irrigation and 0.783 and 0.867 for surface control irrigation system for summer sesame during 2018 and 2019, respectively. Crop growing stage wise water requirement per unit area was estimated for both treatments. Results indicates that among these two methods, NDVI method estimate lowest water requirement in both cases i.e. total water requirement and during all the crop growth stages for both irrigation systems while daily crop water requirement was lower for all growth stages in drip system as compare with control system.
\end{abstract}

Key Words : Basal crop co-efficient, Dual crop co-efficient, Soil evaporation co-efficient; NDVI

How to cite this article : Lakkad, A. P., Patel, S. G., Patel, Vibhuti A. and Varma, M. G. (2021). Application of reflectance based vegetation index to derive dual crop co-efficient for summer sesame. Internat. J. Plant Sci., 16 (AAEBSSD): 62-72, DOI: 10.15740/ HAS/IJPS/16.AAEBSSD/62-72, Copyright@ 2021: Hind Agri-Horticultural Society.

Article chronicle : Received : 10.07.2021; Revised : 13.07.2021; Accepted : 20.07.2021

\section{MEMBERS OF THE RESEARCH FORUM}

Author to be contacted :

A. P. Lakkad, Department of Soil and Water Conservation Engineering, College of Agricultural Engineering and Technology, Navsari Agricultural University, Dediapada (Gujarat) India

Email : larunp@nau.in

Address of the Co-authors:

S.G. Patel, Vibhuti A. Patel and M.G. Varma, College of Agricultural Engineering and Technology, Navsari Agricultural University, Dediapada (Gujarat) India
$\mathrm{I}$ $\mathrm{t}$ is imperative to develop water saving technologies for judicious utilization of available water in agriculture to ensure future food security of the country. A better understanding of the water balance is essential for exploring water-saving techniques. One of the most important concepts regarding water balance is crop evapotranspiration $\left(\mathrm{ET}_{\mathrm{c}}\right.$ ) which is a key factor for determining proper irrigation scheduling and for improving 
water use efficiency in irrigated agriculture. Most of the irrigation scheduling models uses the single $\mathrm{K}_{\mathrm{c}}$ approach to compute $\mathrm{ET}_{\mathrm{c}}$. However for high frequency irrigation using micro irrigation systems for crops that only cover part of the soil, and when the soil is often wetted by rain or irrigation, the dual crop co-efficient approach can lead to more accurate estimates of crop evapotranspiration $E_{\mathrm{c}}$. Dual crop co-efficient $\left(\mathrm{K}_{\mathrm{c}}\right)$ approach permits estimation of the transpiration and evaporation components of evapotranspiration more accurately and capturing impacts of irrigation frequency and total water use during the crop growing season. NDVI is a numerical indicator that uses the visible and near-infrared bands of the electromagnetic spectrum and is adopted to analyse remote sensing measurements and assess whether the target being observed contains live green vegetation or not. Healthy vegetation will have higher value of the NDVI. But from the bare soil, same levels of red and near-infrared light will be reflected and hence they will show the value of NDVI as zero. The study was undertaken to analyse the application of reflectance based vegetation index to derive dual crop co-efficients for summer sesame.

\section{MATERIAL AND METHODS}

\section{Study location:}

A field experiment was conducted during the summer season of 2018 and 2019 at the departmental farm of College of Agricultural Engineering and Technology, Navsari Agricultural University, Dediapada (Gujarat). Research site is situated at $21^{\circ} 37^{\prime} 39^{\prime \prime} \mathrm{N}$ latitude, $73^{\circ} 34^{\prime} 57^{\prime \prime E}$ longitude and at an altitude of 169 $\mathrm{m}$ above the mean sea level. The study area is located in the Dediapada region of Narmada district in the South Gujarat Agro-climatic Zone of Gujarat state. The average annual rainfall of the tract was about $1,139 \mathrm{~mm}$, average maximum and minimum temperature were $34.4{ }^{\circ} \mathrm{C}$ and $22.0{ }^{\circ} \mathrm{C}$, while the average maximum and minimum relative humidity were $73.1 \%$ and $41.5 \%$, respectively. The average annual wind speed was $5.4 \mathrm{~km} \cdot \mathrm{h}^{-1}$, and average annual bright sunshine hour was $7.2 \mathrm{~h}$.

\section{Dual crop co-efficient approach:}

The FAO-56 recommended use of dual crop coefficient approach as a more precise method for determining daily water consumption by plants (Allen et al., 1998). This method uses two types of co-efficients, viz., basal crop co-efficient $\left(\mathrm{K}_{\mathrm{cb}}\right)$, and the soil evaporation co-efficient $\left(\mathrm{K}_{\mathrm{e}}\right)$, for estimation of crop co-efficient for a particular crop growth stage. The actual evapotranspiration $\left(\mathrm{ET}_{\mathrm{a}}\right)$ was calculated from crop coefficient $\mathrm{K}_{\mathrm{c}}$ using Eq. 1.

$$
\mathbf{E T}_{\mathrm{a}}=\mathrm{K}_{\mathrm{c}} \times \mathrm{ET}_{\mathbf{0}}
$$

where,

$\mathrm{ET}_{0}=$ Reference crop evapotranspiration as

estimated using PM method, and

$\mathrm{K}_{\mathrm{c}}=$ Crop co-efficient.

The factor $\mathrm{K}_{\mathrm{c}}$ represents an integrated effect of crop transpiration and soil evaporation in the dual crop coefficient approach and can be expressed by the Eq. 2 (Allen et al., 1998).

$$
\mathbf{K}_{\mathrm{c}}=\mathbf{K}_{\mathrm{cb}}+\mathbf{K}_{\mathrm{e}}
$$

where,

$\mathrm{K}_{\mathrm{cb}}=$ Basal crop co-efficient, represents the transpiration component of the $\mathrm{ET}_{0}$, and

$\mathrm{K}_{\mathrm{e}}=$ Soil water evaporation co-efficient, describes the evaporation component of $\mathrm{ET}_{0}$.

\section{FAO adjusted basal crop co-efficient:}

Basal crop co-efficients for initial, mid and end stages of summer sesame were collected from Table A of FAO Irrigation and Drainage Paper No-56 (Allen et $a l ., 1998)$. The adjusted basal crop co-efficients $\left(\mathrm{K}_{\mathrm{cb}(\mathrm{adj})}\right)$ were derived using Eq. 3 based on local weather parameter of study area.

$$
\begin{aligned}
& \mathbf{K}_{\mathbf{c b}}(\mathbf{e d j},)=\mathbf{K}_{\mathbf{c b}}(\mathrm{Tab})+\left[\mathbf{0 . 0 4}\left(\mathbf{u}_{2}-2\right)-\mathbf{0 . 0 0 4}\left(\mathbf{R H}_{\mathbf{m i n}}-\mathbf{4 5}\right)\right] \frac{\mathbf{h}^{\mathbf{0 . 3}}}{3} \ldots .(3) \\
& \text { where, } \\
& \mathrm{K}_{\mathrm{cb}(\mathrm{Tab})}=\mathrm{K}_{\mathrm{cb} \text { mid }} \text { or } \mathrm{K}_{\mathrm{cbend}}(\text { if } \geq 0.45), \\
& \mathrm{K}_{\mathrm{cb} \text { mid }}=\text { Crop co-efficient } \mathrm{K}_{\mathrm{c}} \text { during mid-season } \\
& \text { stage, } \mathrm{K}_{\mathrm{cbend}}=\text { Crop co-efficient } \mathrm{K}_{\mathrm{c}} \text { at the end of late } \\
& \text { season stage, } \\
& \mathrm{u}_{2}=\text { Mean value for daily wind speed at } 2 \mathrm{~m} \text { height }
\end{aligned}
$$
over grass during the mid or late season growth stage for $1 \mathrm{~m} \cdot \mathrm{s}^{-1} \leq \mathrm{u}_{2} \leq 6 \mathrm{~m} \cdot \mathrm{s}^{-1}, \mathrm{~m} \cdot \mathrm{s}^{-1}$,

$\mathrm{RH}_{\text {min }}=$ Mean value for daily minimum relative humidity during the mid or late season growth stage, $\%$, and

$\mathrm{h}=$ Mean plant height during the crop growing period 2018 and 2019 (Table A), m.

\section{FAO soil evaporation co-efficient:}

Soil evaporation co-efficients were estimated using eq. 4. 
Application of reflectance based vegetation index to derive dual crop co-efficient for summer sesame

\begin{tabular}{|c|c|c|c|c|c|c|c|c|c|}
\hline \multirow{3}{*}{$\begin{array}{l}\text { Sr. } \\
\text { No. }\end{array}$} & \multirow{3}{*}{$\begin{array}{l}\text { Crop development } \\
\text { stage }\end{array}$} & \multicolumn{4}{|c|}{2018} & \multicolumn{4}{|c|}{2019} \\
\hline & & \multicolumn{2}{|c|}{ Plant height, $\mathrm{mm}$} & \multicolumn{2}{|c|}{ Root length, mm } & \multicolumn{2}{|c|}{ Plant height, $\mathrm{mm}$} & \multicolumn{2}{|c|}{ Root length, mm } \\
\hline & & Border & Drip & Border & Drip & Border & Drip & Border & Drip \\
\hline 1. & Initial stage & 44.9 & 46.3 & 60.5 & 57.9 & 46.9 & 45 & 61.1 & 66.1 \\
\hline 2. & Development stage & 222.9 & 263.6 & 95.3 & 92 & 163.9 & 171.8 & 98.8 & 99 \\
\hline 3. & Mid stage & 487.6 & 516.7 & 123.7 & 118.1 & 556.6 & 674.7 & 140 & 123.1 \\
\hline 4. & End stage & 590.3 & 598 & 188.6 & 213.9 & 819.2 & 820.2 & 183.9 & 173.9 \\
\hline
\end{tabular}

$\mathbf{K}_{\mathrm{e}}=\mathbf{K}_{\mathbf{r}}\left(\mathbf{K}_{\mathbf{c m a x}}-\mathbf{K}_{\mathbf{c b}}\right) \leq \mathbf{F}_{\mathbf{e w}} \mathbf{K}_{\mathbf{c m a x}}$

where,

$\mathrm{K}_{\mathrm{e}}=$ Soil evaporation co-efficient,

$\mathrm{K}_{\mathrm{cb}}=$ Basal crop co-efficient,

$\mathrm{K}_{\mathrm{c} \max }=$ Maximum value of $\mathrm{K}_{\mathrm{c}}$ following rain or irrigation,

$\mathrm{K}_{\mathrm{r}}=$ Dimensionless evaporation reduction coefficient dependent on the cumulative depth of water depleted (evaporated) from the topsoil,

$f_{\text {ew }}=$ Fraction of the soil that is both exposed and wetted (fraction of soil surface from which most evaporation occurs), and

$\mathrm{K}_{\mathrm{cmax}}=$ Upper limit of evaporation and transpiration from any cropped surface.

The values of $\mathrm{K}_{\mathrm{cmax}}$ and evaporation reduction coefficient $\left(\mathrm{K}_{\mathrm{r}}\right)$ were computed respectively using Eq. 5 and Eq. 6.

$$
K_{c m a x}=\max \left(\left\{1.2+\left[0.04\left(u_{2}-2\right)-0.004\left(R_{\min }-45\right)\right] \frac{\mathrm{h}^{0.3}}{3}\right\}\left\{K_{\mathrm{cb}}+0.05\right\}\right)
$$

$\mathrm{K}_{\mathbf{r}}=\frac{\text { TAW }- \text { De, } \mathbf{i}-1}{\text { TEW }- \text { REW }}$ for De, $\mathrm{i}-1>$ REW

where,

$\mathrm{K}_{\mathrm{r}}=$ Dimensionless evaporation reduction coefficient dependent on the soil water depletion (cumulative depth of evaporation) from the top soil layer $\left(\mathrm{K}_{\mathrm{r}}=1\right.$ when De, $\left.\mathrm{i}-1 \leq \mathrm{REW}\right)$,

De, $i-1=$ Cumulative depth of evaporation (depletion) from the soil surface layer at the end of day i-1 (the previous day), taken from SIMDualKc model, mm,

TEW (Total Evaporable Water) =Maximum cumulative depth of evaporation (depletion) from the soil surface layer when $\mathrm{K}_{\mathrm{r}}=0$, $\mathrm{mm}$, and

REW (Readily Evaporable Water) $=$ Cumulative depth of evaporation, $\mathrm{mm}$.

\section{Reflectance based vegetation index:}

A vegetation index is a quantitative measure used to measure the biomass or vegetative vigour usually from combination of several spectral bands (range of wavelength), whose values are added, divided, multiplied in order to yield a single value that indicates the amount or vigour of vegetation. The state of the land vegetative condition can be explained with the help of vegetative parameters such as Normalized Difference Vegetative Index (NDVI). NDVI is a numerical indicator that uses the visible and near-infrared bands of the electromagnetic spectrum, and is adopted to analyse remote sensing measurements and assess whether the target being observed contains live green vegetation or not. Healthy vegetation will have higher value of the NDVI. But from the bare soil or rocks same levels of red and near-infrared light will be reflected and hence they will show the value of NDVI as zero. The NDVI values ranges from -1 to +1 (pixel values $0-255$ ). As NDVI values are comparatively convenient to measure either with the help of satellite data or an instrument called NDVI meter.

\section{Plant reflectance: NDVI measurement :}

Normalized difference vegetation index (NDVI) measurements were taken using the Spectrum ${ }^{\circledR}$ FieldScout ${ }^{\circledR}$ CM 1000 NDVI Meter (Spectrum Technologies Inc.). This hand held device can measure areas from $4 \mathrm{~cm}$ to $12 \mathrm{~cm}$ diameter. This is the same methodology that is incorporated in aerial or satellite imagery. The Spectrum CM 1000 NDVI meter displays the NDVI calculation (-1.0 to 1.0). The FieldScout CM 1000 NDVI Meter uses "point-and-shoot" technology to instantly measure reflected light in the red $(660 \mathrm{~nm})$ and near infrared $(840 \mathrm{~nm})$ spectral bands (Hughes et al., 2014). This chlorophyll meter uses red and near infrared reflectance to calculate normalized difference vegetative index (NDVI). Laser guides outline the edges of the measured sample area. An ambient light sensor automatically corrects measurements for varying light conditions. The hand-held meter calculates and displays a running average for multiple readings.

NDVI measurements were made with the instrument about 30 to $45 \mathrm{~cm}$ above and at 90 degree 
angle to the canopy. The NDVI was measured from crop canopy and soil surface at 7 days intervals between 12.00 to 13.00 clocks.

\section{NDVI based basal crop co-efficient:}

NDVI based basal crop co-efficient was derived using equation 7 (Daughtry et al., 1983; Hatfield et al., 1984; Wiegand and Richardson, 1984; Gallo et al., 1985; Gonzalez-Dugo et al., 2008).

$$
K_{c b}=K_{c b} \operatorname{maxx}\left[1-\left(\frac{N D V I_{\max }-N D V I_{a v g}}{N I_{\max }-N D V I_{\min }}\right)^{\mathbf{n}}\right]
$$

where, $\mathrm{K}_{\mathrm{cb} \max }=$ Maximum value of basal crop coefficient.

NDVI $=$ Stage-wise average normalized difference vegetation index.

$\mathrm{NDVI}_{\min }=$ Stage-wise maximum value of NDVI.

$\mathrm{NDVI}_{\text {max }}=$ Stage-wise minimum value of NDVI.

$\mathrm{n}=$ Damping co-efficient.

Maximum basal crop co-efficient $\left(\mathrm{K}_{\mathrm{cb}}\right)$ value of 1.05 for sesame crop was taken from Table 17 of FAO 56 paper (Allen et al., 1998). The stage-wise values of $\mathrm{NDVI}_{\text {min }}, \mathrm{NDVI}_{\max }$ and NDVI were calculated using measured NDVI values. Damping co-efficient (n) was estimated using equation 8. (Bausch and Neale, 1990; D'Urso and Calera, 2006).

$$
\mathbf{n}=\frac{\mathbf{K}}{\mathbf{K}^{\prime}}
$$

The value of $\mathrm{K}$ ranges from 0.50 to 0.70 (Er- Raki et al., 2007). The value of $\mathrm{K}$ was taken as 0.59 for this study using Fig. No. 9 (Hunsakar et al., 2005) for sesame whiles the value of $\mathrm{K}^{\prime}$ was calculated using equation 9 (Ashrar et al., 1984).

$$
\mathbf{K}^{\prime}=\frac{0.5}{\cos \boldsymbol{\theta}}
$$

where, $\theta$ is a solar zenith angle.

The solar zenith angle is the angle between the zenith and the centre of the Sun's disc. The solar zenith angles were calculated using online NOAA ESRL Solar Position Calculator at $12.30 \mathrm{pm}$ for the day of measurement of crop NDVI (https://www.esrl.noaa. $\mathrm{gov} / \mathrm{gmd} / \mathrm{grad} /$ solcalc/azel.html).

\section{NDVI Based Soil evaporation co-efficient:}

Soil evaporation co-efficient was estimated by using equation 10 (Er- Raki et al., 2007).

$$
K_{e}=0.18 \times\left(1-f_{c}\right)
$$

where, $\mathrm{K}_{\mathrm{e}-}=$ Soil evaporation co-efficient

$\mathrm{f}_{\mathrm{c}}=$ Fraction of ground cover

The value of 0.18 is taken from Fig. 29 of FAO 56 Paper (Allen et al., 1998)

\section{Fraction of ground cover:}

Fraction of ground cover can be calculated using equation 11 (Er- Raki et al., 2007)

$$
\mathbf{f}_{\mathrm{c}}=\left(\mathbf{N D V I}_{\text {avg }}-\mathbf{N D V I}_{\text {min }}\right)
$$

where, NDVI $_{\text {avg }}=$ Stage-wise average normalized difference vegetation index.

$\mathrm{NDVI}_{\min }=$ Stage-wise minimum value of NDVI.

\section{Estimation of crop water requirement:}

In this study, crop water requirement of summer sesame crop has been estimated. Crop water requirement is the amount of water needed to meet the water loss through evapotranspiration of the field. Estimation of the crop water requirement is derived from crop evapotranspiration (crop water use) which is the product of the references evapotranspiration $\left(\mathrm{ET}_{0}\right)$ and the crop co-efficient $\left(\mathrm{K}_{\mathrm{c}}\right)$. The reference evapotranspiration $\left(\mathrm{ET}_{0}\right)$ was estimated based on FAO Penman-Monteith method ( $\mathrm{ET}_{0}$ calculator), using climate data (Allen et al., 1998).

$$
\begin{aligned}
& \mathbf{E T}_{\mathrm{c}}=\mathbf{E T}_{\mathbf{0}} \times \mathbf{K}_{\mathrm{c}} \\
& \text { where, }_{\mathrm{c}} \text { ET } \\
& \mathrm{ET}_{\mathrm{c}}=\text { Actual evapotranspiration }(\mathrm{mm} / \mathrm{day}) \\
& \mathrm{K}_{\mathrm{c}}=\text { Reference evapotranspiration }(\mathrm{mm} / \text { day) }
\end{aligned}
$$

\section{RESULTS AND DISCUSSION}

The results obtained from the present investigation as well as relevant discussion have been summarized under following heads :

\section{FAO dual crop co-efficient: \\ FAO basal crop co-efficient:}

Basal crop co-efficient values for the three stages of initial, mid and end stage for summer sesame are 0.15 , 1.05 and 0.20 respectively in FAO-56 paper (Allen et al., 1998). These basal crop co-efficient values for summer sesame was adjusted for the study area from local data of daily wind speed, $\mathrm{RH}_{\text {min }}$ and crop height using Eq. 3 for both the years and presented in Table 1.

\section{FAO soil evaporation co-efficient:}

Crop growth stage wise soil evaporation coefficient for summer sesame was estimated for the study 
Application of reflectance based vegetation index to derive dual crop co-efficient for summer sesame

area using $\mathrm{K}_{\mathrm{c} \max }$ (maximum value of $\mathrm{K}_{\mathrm{c}}$ following rain or irrigation), Reduction co-efficient $\left(\mathrm{K}_{\mathrm{r}}\right)$ and fraction of soil surface from which most evaporation occurs $\left(f_{\text {ew }}\right)$ by using Eq. 6 for both the years while $\mathrm{K}_{\text {cmax }}$ were derived from Eq. 5. Readily Evaporable Water (REW) and Total Evaporable Water (TEW) are required to estimate reduction co-efficient $\left(\mathrm{K}_{\mathrm{r}}\right)$. REW and TEW were adopted as 9 and 20 respectively for clay loam soil as given in FAO paper 56 (Allen et al., 1998). Crop growing stage wise $\mathrm{K}_{\mathrm{r}}$ and $\mathrm{K}_{\mathrm{cmax}}$ values are presented in Table 2.

Soil evaporation co-efficient was estimated on daily basis using Eq. 4 and presented in Table 3. These values were used to derive daily dual crop co-efficient.

As per Table 3, values of soil evaporation coefficient $\mathrm{K}_{\mathrm{e}}$ are highest during initial stage because of more than $90 \%$ area of cropped field were not covered by crop canopy and exposed to atmosphere. While from development to end stage, the values of soil evaporation co-efficient $\mathrm{K}_{\mathrm{e}}$ decrease sequentially because of continuously increase of crop canopy cover of cropped field during this period. During end stage, these values were slightly decrease because of irrigation of the field

\begin{tabular}{|c|c|c|c|c|}
\hline \multirow{2}{*}{ Sr. No. } & \multirow{2}{*}{ Year } & \multirow{2}{*}{ Crop development stage } & Drip irrigation system & Surface control irrigation system \\
\hline & & & $\mathrm{K}_{\text {dbadj }}$ & $\mathrm{K}_{\text {cbadj }}$ \\
\hline \multirow{4}{*}{1.} & \multirow{4}{*}{2018} & Initial stage & 0.13 & 0.13 \\
\hline & & Development stage & 0.48 & 0.48 \\
\hline & & Mid stag & 0.81 & 0.80 \\
\hline & & End stage & 0.24 & 0.24 \\
\hline \multirow{4}{*}{2.} & \multirow{4}{*}{2019} & Initial stage & 0.12 & 0.12 \\
\hline & & Development stage & 0.47 & 0.48 \\
\hline & & Mid stage & 0.80 & 0.80 \\
\hline & & End stage & 0.26 & 0.26 \\
\hline
\end{tabular}

\begin{tabular}{|c|c|c|c|c|c|c|}
\hline \multirow{2}{*}{ Sr. No. } & \multirow{2}{*}{ Year } & \multirow{2}{*}{ Crop development stages } & \multicolumn{2}{|c|}{ Drip irrigation system } & \multicolumn{2}{|c|}{ Surface control irrigation system } \\
\hline & & & $\mathrm{K}_{\mathrm{r}}$ & $\mathrm{K}_{\mathrm{c} \max }$ & $\mathrm{K}_{\mathrm{r}}$ & $\mathrm{K}_{\mathrm{cmax}}$ \\
\hline \multirow{4}{*}{1.} & \multirow{4}{*}{2018} & Initial stage & 0.51 & 1.18 & 0.57 & 1.18 \\
\hline & & Development stage & 0.51 & 1.20 & 0.65 & 1.20 \\
\hline & & Mid stage & 0.52 & 1.24 & 0.56 & 1.24 \\
\hline & & End stage & 0.41 & 1.24 & 0.48 & 1.24 \\
\hline \multirow{4}{*}{2.} & \multirow{4}{*}{2019} & Initial stage & 0.57 & 1.17 & 0.57 & 1.17 \\
\hline & & Development stage & 0.58 & 1.19 & 0.66 & 1.20 \\
\hline & & Mid stage & 0.38 & 1.23 & 0.56 & 1.23 \\
\hline & & End stage & 0.38 & 1.26 & 0.49 & 1.26 \\
\hline
\end{tabular}

\begin{tabular}{|c|c|c|c|c|}
\hline Sr. No. & Year & Crop development stage & Drip irrigation system & Surface control irrigation system \\
\hline \multirow{4}{*}{1.} & \multirow{4}{*}{2018} & Initial stage & 0.53 & 0.59 \\
\hline & & Development stage & 0.36 & 0.51 \\
\hline & & Mid stage & 0.21 & 0.25 \\
\hline & & End stage & 0.41 & 0.48 \\
\hline \multirow{4}{*}{2.} & \multirow{4}{*}{2019} & Initial stage & 0.60 & 0.60 \\
\hline & & Development stage & 0.48 & 0.49 \\
\hline & & Mid stage & 0.16 & 0.25 \\
\hline & & End stage & 0.38 & 0.49 \\
\hline
\end{tabular}


was terminated during maturity period of crop.

\section{FAO crop co-efficient:}

Crop co-efficient $\left(\mathrm{K}_{\mathrm{c}}\right)$ for each growth stages of summer sesame crop was derived by summation of basal crop co-efficient (Table 1) and soil evaporation coefficient (Table 3 ) for each stages and presented in Table 4. Table 4 Depicts that crop co-efficient values are increase from initial to mid stage of crop period while during end stage they decrease for both the treatment during both years.

NDVI based basal crop co-efficient $\left(K_{c b}\right)$ :

Crop growth stage wise basal crop co-efficient for summer sesame was estimated for the study area using Eq. 7 and presented in Table 5.

\section{NDVI based soil evaporation co-efficient:}

Crop growth stage wise soil evaporation coefficient values for summer sesame was estimated for the study area using Eq. 10 and $f_{c}$ (fraction of ground cover) was estimated using Eq. 11 for both the years and presented in Table 6 .

\section{NDVI based crop co-efficient $\left(K_{c}\right)$ :}

Crop co-efficient $\left(\mathrm{K}_{\mathrm{c}}\right)$ for each growth stages of summer sesame crop was derived by summation of basal crop co-efficient $\left(\mathrm{K}_{\mathrm{cb}}\right)$ and soil evaporation co-efficient

\begin{tabular}{|c|c|c|c|c|}
\hline Sr. No & Year & Crop development stage & Drip irrig ation system & Surface control irrigation system \\
\hline \multirow{4}{*}{1.} & \multirow{4}{*}{2018} & Initial stage & 0.66 & 0.72 \\
\hline & & Development stage & 0.84 & 0.99 \\
\hline & & Mid stage & 1.02 & 1.05 \\
\hline & & End stage & 0.65 & 0.72 \\
\hline \multirow{4}{*}{2.} & \multirow{4}{*}{2019} & Initial stage & 0.72 & 0.73 \\
\hline & & Development stage & 0.95 & 0.97 \\
\hline & & Mid stage & 1.06 & 1.05 \\
\hline & & End stage & 0.64 & 0.74 \\
\hline
\end{tabular}

\begin{tabular}{|c|c|c|c|c|}
\hline Sr. No. & Year & Crop development stage & Drip irrigation system & Control irrigation system \\
\hline \multirow{4}{*}{1.} & \multirow{4}{*}{2018} & Initial stage & 0.38 & 0.37 \\
\hline & & Development stage & 0.57 & 0.45 \\
\hline & & Mid stage & 0.63 & 0.63 \\
\hline & & End stage & 0.39 & 0.39 \\
\hline \multirow{4}{*}{2.} & \multirow{4}{*}{2019} & Initial stage & 0.43 & 0.35 \\
\hline & & Development stage & 0.53 & 0.45 \\
\hline & & Mid stage & 0.59 & 0.62 \\
\hline & & End stage & 0.50 & 0.32 \\
\hline
\end{tabular}

\begin{tabular}{|c|c|c|c|c|}
\hline Sr. No. & Year & Crop development stage & Drip irrigation system & Control irrigation system \\
\hline \multirow{4}{*}{1.} & \multirow{4}{*}{2018} & Initial stage & 0.17 & 0.16 \\
\hline & & Development stage & 0.16 & 0.15 \\
\hline & & Mid stage & 0.14 & 0.14 \\
\hline & & End stage & 0.15 & 0.12 \\
\hline \multirow{4}{*}{2.} & \multirow{4}{*}{2019} & Initial stage & 0.16 & 0.16 \\
\hline & & Development stage & 0.16 & 0.15 \\
\hline & & Mid stage & 0.15 & 0.14 \\
\hline & & End stage & 0.16 & 0.16 \\
\hline
\end{tabular}


Application of reflectance based vegetation index to derive dual crop co-efficient for summer sesame

$\left(\mathrm{K}_{\mathrm{e}}\right)$ for each stages and presented in Table 7. Table 7 Depicts that crop co-efficient values are increase from initial to mid stage of crop period while during end stage they decrease for both the treatment during both years.

\section{Comparison of FAO adjusted $K_{c}$ and NDVI based} $K_{c}$ for drip irrigation system:

FAO estimated crop co-efficient $\left(\mathrm{K}_{\mathrm{c}}\right)$ values using FAO 56 method (Allen et al., 1998) were compared with NDVI based crop co-efficient $\left(\mathrm{K}_{\mathrm{c}}\right)$. Results showed that there exists a linear relation between the FAO estimated $\mathrm{K}_{\mathrm{c}}$ and NDVI $\mathrm{K}_{\mathrm{c}}$. The co-efficient of determination of the fitted regression equation was found to be 0.836 and 0.765 during summer sesame during 2018 and 2019, respectively for drip irrigation system as shown in Fig. 1.

Comparison of FAO adjusted $K_{c}$ and NDVI $K_{c}$ for control irrigation system:

FAO estimated crop co-efficient $\left(\mathrm{K}_{\mathrm{c}}\right)$ values using FAO 56 method (Allen et al., 1998) were compared with NDVI based crop co-efficient $\left(\mathrm{K}_{\mathrm{c}}\right)$. Results showed that there existed a linear relation between the FAO estimated $\mathrm{K}_{\mathrm{c}}$ and NDVI $\mathrm{K}_{\mathrm{c}}$. The co-efficient of determination of the fitted regression equation was found to be 0.783 and 0.867 during summer sesame during 2018 and 2019, respectively for surface control irrigation system as shown in Fig. 2.

\begin{tabular}{|c|c|c|c|c|}
\hline Sr. No. & Year & Crop development stage & Drip irrigation system & Control irrigation system \\
\hline \multirow{4}{*}{1.} & \multirow{4}{*}{2018} & Initial stage & 0.57 & 0.53 \\
\hline & & Development stage & 0.67 & 0.60 \\
\hline & & Mid stage & 0.71 & 0.78 \\
\hline & & End stage & 0.48 & 0.51 \\
\hline \multirow{4}{*}{2.} & \multirow{4}{*}{2019} & Initial stage & 0.59 & 0.51 \\
\hline & & Development stage & 0.69 & 0.60 \\
\hline & & Mid stage & 0.75 & 0.77 \\
\hline & & End stage & 0.66 & 0.48 \\
\hline
\end{tabular}

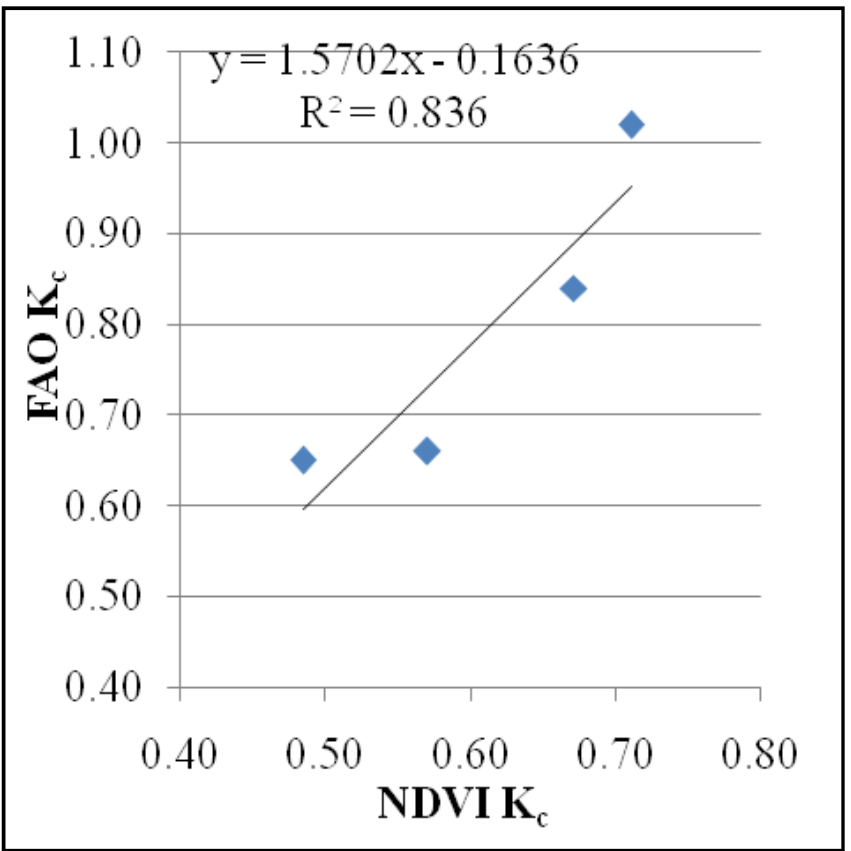

2018

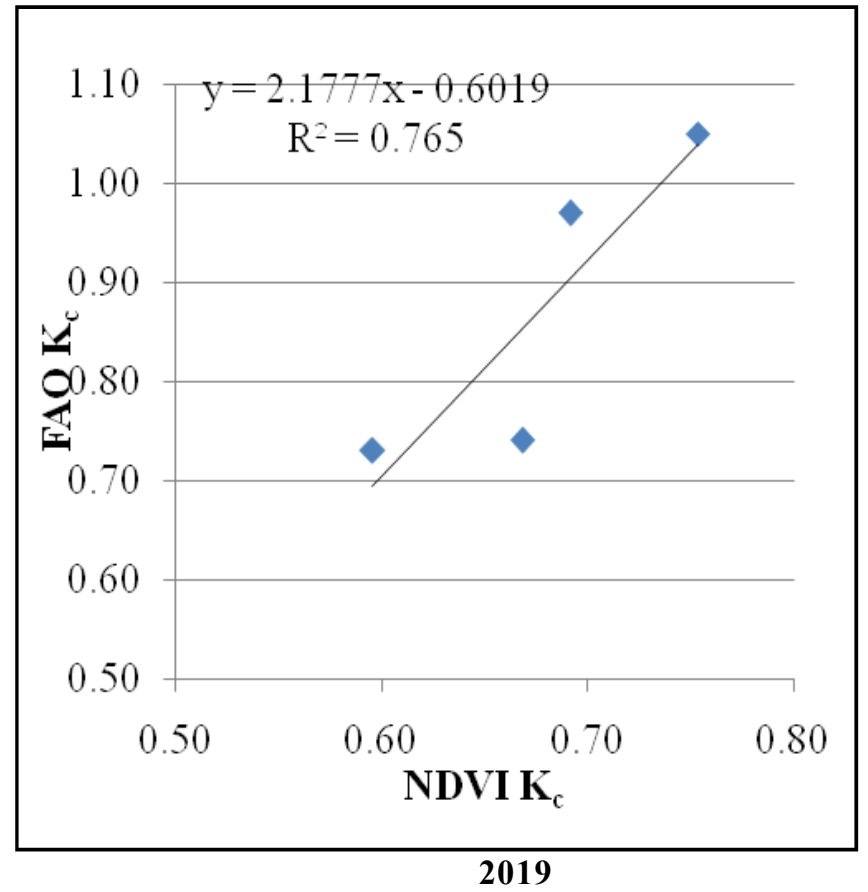

Fig. 1: Comparison between the NDVI $K_{c}$ and FAO $K_{c}$ for drip irrigation system 


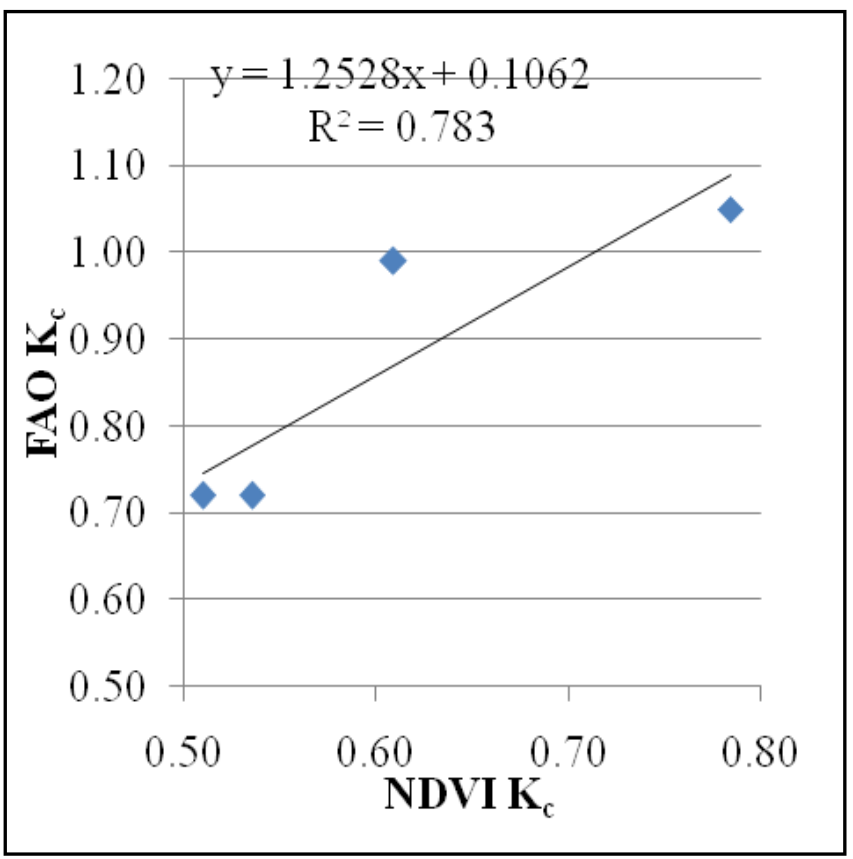

2018

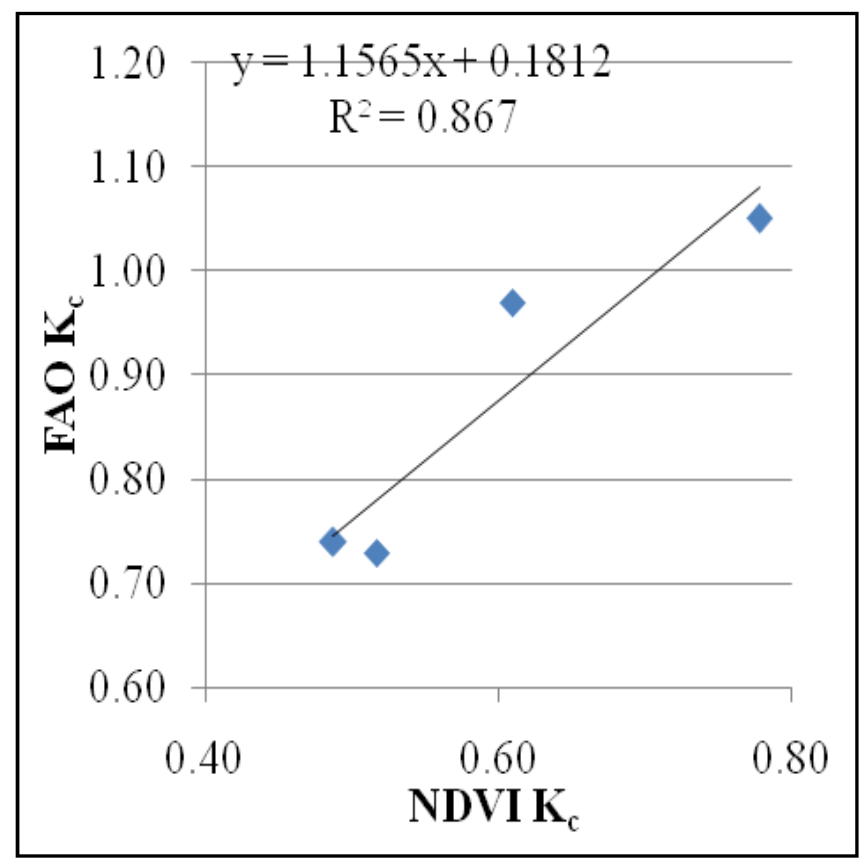

2019

Fig 2 : Comparison between the NDVI $K_{c}$ and FAO $K_{c}$ for control irrigation system

\section{Crop water requirement:}

Crop water requirement using FAO adjusted $K_{c}$ :

The stage wise water requirements of summer sesame were estimated using estimated FAO adjusted crop co-efficient $\left(\mathrm{K}_{\mathrm{c}}\right)$ and reference evapotranspiration $\left(\mathrm{ET}_{0}\right)$ for both years 2018 and 2019 and presented in Table 8 . It shows that daily crop water requirement was lower for all growth stages in drip system as compare with control system.

\section{Crop water requirement using NDVI $K_{c}$ :}

The stage wise daily water requirements of summer sesame estimated using NDVI based $\mathrm{K}_{\mathrm{c}}$ and reference evapotranspiration $\left(\mathrm{ET}_{0}\right)$ are presented in Table 10 for both year of 2018 and 2019. The table shows that daily crop water requirement was lower during initial and development stages in drip system as compared with control system while daily crop water requirement was higher during mid stage in control system as compare with drip system.

Crop growing stage wise water requirement for summer sesame:

Crop growing stage wise crop water requirement of summer sesame estimated through dual crop coefficient approach using FAO 56 method and NDVI method are presented in Table 10 and Table 11. The table shows that irrigation by surface control irrigation

\begin{tabular}{ccccc}
\hline \multicolumn{2}{l}{ Table 8 : Crop water requirement using FAO crop co-efficient method } & & \multicolumn{2}{c}{ Average crop water requirement (mm/day) } \\
\hline \multirow{2}{*}{ Sr. No. } & Year & \multicolumn{1}{c}{ Crop development stages } & Drip irrigation system & Surface control irrigation system \\
\cline { 3 - 4 } & & Initial stage & 2.81 & 3.13 \\
& & Development stage & 4.40 & 5.21 \\
1. & \multirow{2}{*}{2018} & Mid stage & 5.82 & 6.00 \\
& & End stage & 4.88 & 5.41 \\
& & Initial stage & 3.22 & 3.23 \\
2. & Development stage & 5.45 & 5.54 \\
& & Mid stage & 6.15 & 6.74 \\
\end{tabular}


Application of reflectance based vegetation index to derive dual crop co-efficient for summer sesame

\begin{tabular}{|c|c|c|c|c|}
\hline \multirow{2}{*}{ Sr. No. } & \multirow{2}{*}{ Year } & \multirow{2}{*}{ Crop development stages } & \multicolumn{2}{|c|}{ Average crop water requirement ( $\mathrm{mm} /$ day) } \\
\hline & & & Drip irrigation system & Control irrigation system \\
\hline \multirow{4}{*}{1.} & \multirow{4}{*}{2018} & Initial stage & 2.58 & 2.42 \\
\hline & & Development stage & 3.59 & 3.26 \\
\hline & & Mid stage & 4.29 & 4.73 \\
\hline & & End stage & 3.67 & 3.86 \\
\hline \multirow{4}{*}{2.} & \multirow{4}{*}{2019} & Initial stage & 2.74 & 2.38 \\
\hline & & Development stage & 4.15 & 3.66 \\
\hline & & Mid stage & 4.97 & 5.14 \\
\hline & & End stage & 5.61 & 4.09 \\
\hline
\end{tabular}

\begin{tabular}{|c|c|c|c|c|}
\hline \multicolumn{5}{|c|}{ Table 10 : Total water requirement $(\mathrm{mm})$ for drip irrigation system } \\
\hline Sr. No. & Year & Crop development stages & FAO method & NDVImethod \\
\hline \multirow{4}{*}{1.} & \multirow{4}{*}{2018} & Initial stage & 56.25 & 51.64 \\
\hline & & Development stage & 132.00 & 107.86 \\
\hline & & Mid stage & 174.60 & 128.75 \\
\hline & & End stage & 48.87 & 36.71 \\
\hline \multirow{6}{*}{2.} & \multirow{6}{*}{2019} & Total & 411.72 & 324.96 \\
\hline & & Initial stage & 64.46 & 54.90 \\
\hline & & Development stage & 163.57 & 124.66 \\
\hline & & Mid stage & 184.55 & 149.36 \\
\hline & & End stage & 52.78 & 56.18 \\
\hline & & Total & 465.36 & 385.11 \\
\hline
\end{tabular}

\begin{tabular}{|c|c|c|c|c|}
\hline Sr. No. & Year & Crop development stages & FAO method & NDVI method \\
\hline \multirow{4}{*}{1.} & \multirow{4}{*}{2018} & Initial stage & 62.65 & 48.51 \\
\hline & & Development stage & 156.30 & 97.97 \\
\hline & & Mid stage & 180.00 & 142.06 \\
\hline & & End stage & 54.14 & 38.65 \\
\hline \multirow{6}{*}{2.} & \multirow{6}{*}{2019} & Total & 453.09 & 327.20 \\
\hline & & Initial stage & 64.63 & 47.65 \\
\hline & & Development stage & 166.22 & 109.85 \\
\hline & & Mid stage & 202.28 & 154.19 \\
\hline & & End stage & 62.65 & 40.99 \\
\hline & & Total & 495.78 & 352.70 \\
\hline
\end{tabular}

system requires more water as compare to drip irrigation system while total crop water requirement is lowest in case of NDVI method among these two methods.

Crop growing stage wise water requirement per unit area was estimated for both treatments. Table 9 and 10 indicates that among these two methods, NDVI method estimate lowest water requirement in both cases i.e. total water requirement and during all the crop development stages for both irrigation systems. The study indicates that NDVI $\mathrm{K}_{\mathrm{c}}$ model can estimate actual crop co-efficient and accurate daily water requirement in case of drip irrigation system. Total water requirement was highest in case of FAO method while it was lower in case of NDVI method for both irrigation systems. 
A. P. Lakkad, S. G. Patel, Vibhuti A. Patel and M. G. Varma

\section{Conclusion:}

Based on the results obtained at various stages of methodology, following conclusions could be drawn:

- The co-efficient of determination $\left(\mathrm{R}^{2}\right)$ for NDVI based $\mathrm{K}_{\mathrm{c}}$ compared with FAO adjusted $\mathrm{K}_{\mathrm{c}}$ were 0.836 $\& 0.765$ for drip system and $0.783 \& 0.867$ for control system for 2018 and 2019, respectively.

- In case of FAO 56 method, total water requirement of summer sesame was estimated at 411.6 and $465.1 \mathrm{~mm}$ per unit area in drip system and 453 and $495.6 \mathrm{~mm}$ per unit area in control system for both year 2018 and 2019, respectively. In FAO 56 method water saving in drip system as compare to control system is 9.14 and $6.05 \%$ for both year 2018 and 2019 , respectively.

- In case of Normalized Difference Vegetation Index (NDVI) method, total water requirement of summer sesame was estimated at 324.96 and 385.11 $\mathrm{mm} /$ unit area in drip system and 327.20 and $352.70 \mathrm{~mm} /$ unit area in control system for both year 2018 and 2019. In NDVI method, the water saving in drip system as compare to control system is 0.69 and $-9.18 \%$ for both year 2018 and 2019, respectively.

- Dual crop co-efficient values estimated in the study region was varying from the FAO-56 reported values at different growth stages for sesame. Therefore, it can be concluded that the regional crop co-efficient $\left(\mathrm{K}_{\mathrm{c}}\right)$ values need to be estimated and used for more accurate irrigation scheduling at regional scales.

- Among these two methods used in this study, NDVI method is more appropriate because it can provide more reliable and actual crop co-efficient and crop water requirement for the study region for summer sesame crop.

\section{REFERENCES}

Allen, R. G., Pereira, L. S., Raes, D. and Smith, M. (1998). Crop evapotranspiration: guidelines for computing crop water requirements. Irrigation and Drainage Paper 56, UN-FAO, Rome, Italy.

Allen, R. G. (2000). Using the FAO-56 dual crop co-efficient method over an irrigated region as part of an evapotranspiration intercomparison study. Journal of Hydrology, 229 (1-2): 27-41.

Allen, R. G., Pereira, L. S., Smith, M., Raes, D. and Wright, J. L. (2005). FAO-56 dual crop co-efficient method for estimating evaporation from soil and application extensions. Journal of Irrigation and Drainage Engineering, 131(1) : 2-13.
Allen, R. G., Tasumi, M. and Trezza, R. (2007). Satellite-based energy balance for mapping evapotranspiration with internalized calibration (METRIC) —Model. Journal of Irrigation and Drainage Engineering, 133(4) : 380-394.

Allen, R.G. and Pereira, L. S. (2009). Estimating crop co-efficients from fraction of ground cover and height. Irrigation Science, 28(1): 17-34.

Ashrar, G., Kanemasu, E. T. and Yoshida, M. (1984). Estimates of leaf area index from spectral reflectance of wheat under different cultural practices and solar angle. Remote Sensing of Environment, 17(1) : 1-11.

Bausch W. C. and Neale C. M. U. (1990). Spectral inputs improve corn crop co-efficients and irrigation scheduling. Transactions of the American Society of Agricultural Engineering, 32(6), 1901-1908.

Daughtry, C. S. T., Gallo, K. P. and Bauer, M. E. (1983). Spectral estimates of solar radiation intercepted by corn canopies, Agronomy Journal. 75(4) : 527-531.

Doorenbos, J. and Pruitt, W.O. (1977). Guidelines for predicting crop water requirements. FAO Irrigation and Drainage Paper. No. 52. Rome. FAO (p. 156). ISBN 92-5-400279-8.

D’Urso, G. and Calera Belmonte, A. (2006). Operative approaches to determine crop water requirements from Earth Observation data: methodologies and applications. In AIP conference proceedings, $\mathbf{8 5 2}$ (1): $14-25$.

Er-Raki, S., Chehbouni, A., Guemouria, N., Duchemin, B., Ezzahar, J. and Hadria, R. (2007). Combining FAO-56 model and ground-based remote sensing to estimate water consumptions of wheat crops in a semi-arid region. Agricultural Water Management, 87(1) : 4154.

Er-Raki, S., A. L. A. H., Chehbouni, A., Guemouria, N., Ezzahar, J., Khabba, S., Boulet, G. and Hanich, L. (2009). Citrus orchard evapotranspiration: comparison between eddy covariance measurements and the FAO-56 approach estimates. Plant Biosystems, 143(1) : 201208.

Gallo, K. P., Daughtry, C. S. T. and Bauer, M. E. (1985), Spectral estimation of absorbed photosynthetically active radiation in corn canopies. Remote Sensing Environmental Science, 17: 221-232.

González-Dugo, M. P. and Mateos, L. (2008). Spectral vegetation indices for benchmarking water productivity of irrigated cotton and sugarbeet crops. Agricultural Water Management, 95(1) : 48-58. 
Application of reflectance based vegetation index to derive dual crop co-efficient for summer sesame

Hatfield, J. L., Asrar, G. and Kanemasu, E. T. (1984). Intercepted photosynthetically active radiation estimated by spectral reflectance, Remote Sensing and Environmental Science, 14 : 65-75.

Hunsaker D. J., Pinter P. J. and Kimball, B. A. (2005). Wheat basal crop co-efficients determined by normalized difference vegetation index. Irrigation Science, 24(1): $1-14$.

Wiegand, C. L. and Richardson, A. J. (1984). Leaf area, light interception and yield estimates from spectral components analysis 1. Agronomy Journal, 76(4) : 543-548.

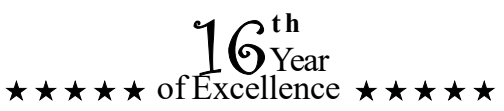

